\title{
Subchronic toxicity of Nile tilapia with different exposure routes to Microcystis aeruginosa: Histopathology, liver functions, and oxidative stress biomarkers
}

\author{
H. M. R. Abdel-Latif ${ }^{1}$ and A. M. Abou Khashaba²
}

1. Department of Poultry and Fish Diseases, Faculty of Veterinary Medicine, Alexandria University (Matrouh Branch), Fuka City, Box: 51744, Matrouh Province, Egypt; 2. Department of Food Inspection, Animal Health Research Institute, Dokki, Giza Province, Egypt.

Corresponding author: H. M. R. Abdel-Latif, e-mail: hmhany@alexu.edu.eg

Co-author: AMAK: dr.abou.khashaba@gmail.com

Received: 21-05-2017, Accepted: 28-07-2017, Published online: 21-08-2017

doi: 10.14202/vetworld.2017.955-963 How to cite this article: Abdel-Latif HMR, Khashaba AMA (2017) Subchronic toxicity of Nile tilapia with different exposure routes to Microcystis aeruginosa: Histopathology, liver functions, and oxidative stress biomarkers, Veterinary World, 10(8): 955-963.

\begin{abstract}
Background: Toxic cyanobacterial blooms (Microcystis aeruginosa contains microcystins [MCs]) have been reported to induce clinicopathological alterations as well as different oxidative stress in aquatic biota.
\end{abstract}

Aim: Three-week subchronic exposure experiment was carried out on Nile tilapia, to determine their effects on fish behavior, tissues, liver functions, antioxidant enzymes, and lipid peroxidation.

Materials and Methods: Fish were exposed to four main treatments; orally fed diet plus toxic cells of $M$. aeruginosa (containing $3500 \mu \mathrm{g} / \mathrm{g}$ MC-LR), immersion in $500 \mu \mathrm{g} \mathrm{MC}-\mathrm{LR} / \mathrm{L}$, intraperitoneal injection of M. aeruginosa MC-LR with a dose of $0.1 \mathrm{ml}$ of extracted toxin at a dose of $200 \mu \mathrm{g} / \mathrm{kg}$ bwt, and the fourth one served as a control group, then the fish were sacrificed at the end of $3^{\text {rd }}$ week of exposure.

Results: The results revealed no recorded mortality with obvious behavioral changes and an enlarged liver with the congested gall bladder. Histopathology demonstrated fragmentation, hyalinization, and necrosis of the subcutaneous musculature marked fatty degeneration, and vacuolation of hepatopancreatic cells with adhesion of the secondary gill lamellae associated with severe leukocytic infiltration. Furthermore, liver functions enzymes (aspartate aminotransferase and alanine aminotransferase, and the activities of glutathione peroxidase, glutathione reductase, lipid peroxidase, and catalase enzymes) were significantly increased in all treatments starting from the $2^{\text {nd }}$ week as compared to the control levels.

Conclusion: In this context, the study addresses the possible toxicological impacts of toxic M. aeruginosa contain MC-LR to Nile tilapia, and the results investigated that MC-LR is toxic to Nile tilapia in different routes of exposure as well as different doses.

Keywords: catalase, lipid peroxidation, Microcystis aeruginosa, microcystins, Nile tilapia.

\section{Introduction}

Nile tilapia is one of the major cultured species worldwide, particularly in Egypt [1], with a yearly growth rate of about $12.2 \%$ [2]. Toxic cyanobacterial algal blooms (especially Microcystis aeruginosa) produce potent cyanotoxins known as microcystins (MCs) $[3,4]$, which could be accumulated in fish tissues and organs from freshwater lakes $[5,6]$. MCs-LR is the predominantly potent hepatotoxin for aquatic biota [7,8] and possibly cause mass kills of fish [9].

Several reviews were demonstrated the toxicity of these toxic cyanobacterial blooms containing MC-LR on Nile tilapia in various localities in Egypt,

Copyright: Abdel-Latif and Khashaba. Open Access. This article is distributed under the terms of the Creative Commons Attribution 4.0 International License (http://creativecommons.org/licenses/ by/4.0/), which permits unrestricted use, distribution, and reproduction in any medium, provided you give appropriate credit to the original author(s) and the source, provide a link to the Creative Commons license, and indicate if changes were made. The Creative Commons Public Domain Dedication waiver (http:// creativecommons.org/publicdomain/zero/1.0/) applies to the data made available in this article, unless otherwise stated. whereas heavy kills were at Sharkia, Alexandria, the Nile River, and several irrigation canals [10-13], and there are yearly greater records of these blooms; this may be due to the high water temperature throughout the year and the abundance of environmental pollutants.

The toxicological impacts of the cyanobacteria toxic algae and their toxins in fish were widely assessed and discussed before, whereas numerous hepatotoxicity and renal toxicity histopathological signs were demonstrated in Cyprinus carpio [14], Oreochromis mossambicus [15], and in Oreochromis niloticus [16]. In addition, one of the biochemical characteristics of MCs toxicity is the production of reactive oxygen species, which is responsible for oxidative stress responses of the exposed fish [17].

The antioxidant enzymes were elevated with the MC-LR toxicity in Nile tilapia [18-20] and in early life stages of the zebrafish [21]. The previous reviews were based mainly on time-dependent manner. Therefore, this study was to demonstrate the impacts of subchronic exposure of these toxic cyanobacteria 
and their MC (MC-LR) in terms of histopathological findings, lipid peroxidation (LPO), and oxidative stress biomarkers of Nile tilapia based on time- and dose-dependent manners using different three main experimentally exposure toxicity (immersion, feed incorporation, and intraperitoneal injection).

\section{Materials and Methods}

\section{Ethical approval}

The approval from the Institutional Animal Ethics Committee to carry out this study was not required as no invasive technique was used.

\section{Experimental design and fish rearing}

This study was conducted on 160 fish, Nile tilapia (O. niloticus) with mean weight $50 \pm 10 \mathrm{~g}$. They were obtained from a private farm in Kafr El-Sheikh Province, Egypt, and were transferred as soon as possible to the laboratory where they were held in eight aquaria, each with $60 \mathrm{~L}$ of fresh chlorine-free tap water (overnight 3 days prior the experiments). The aquaria were set up with continuous water siphoning and pump aerators, and the temperature was kept constant $\left(24 \pm 3^{\circ} \mathrm{C}\right)$. Dissolved oxygen values were maintained in between 4.5 and $5.0 \mathrm{mg} / \mathrm{L}$. Fish were left to be acclimated 2 weeks prior the start of the experiments. Fish were hand fed on a commercial diet containing $28 \%$ protein 2 times daily, $3 \%$ of body weight of fish, and fish wastes were siphoned weekly.

\section{Toxic algae}

The assemblage of algal cells and MCs

MCs were extracted from dried $M$. aeruginosa algal blooms, which thereby collected from the drainage canal of Mariout Lake, Egypt. Lyophilized algal cells $(50 \mathrm{mg})$ were extracted 3 times with $10 \mathrm{ml}$ of $0.1 \mathrm{M}$ acetic acid, and $20 \mathrm{ml}$ of a combined mix of both chloroform and methanol added $(1: 1 \mathrm{v} / \mathrm{v})$. The algal suspension was sonicated in an ultrasound bath for $15 \mathrm{~min}$, stirred for $30 \mathrm{~min}$ at room temperature, and then centrifuged at $4500 \mathrm{rpm}$ for $15 \mathrm{~min}$.

\section{Demonstration of MCs: Types and quantity}

High-performance liquid chromatography analysis was used for separation of the crude extract concentrations of MCs, using standard solutions of MCs (Novabiochem, Nottingham, UK) prepared in methanol $(500 \mu \mathrm{g} / \mathrm{ml})$ and diluted as required with methanol for use as working solutions $(0.5-5.0 \mathrm{mg} / \mathrm{L}$ of each toxin) [22], whereas the main toxin of MCs produced is (MC-LR). MC-YR and MC-LF were not found in our isolated strain from the examined locality. Furthermore, MC-RR was found in small quantity $(<0.50 \%$ of the total toxins produced/g dry algae).

\section{Toxicity bioassay}

Subchronic in vivo exposure and experimental designs

Fish were experimentally exposed to cyanobacterial toxic algal cells containing MC-LR for 3 weeks' in vivo exposure period by different exposure methods; intraperitoneal injection of MC-LR (IPM), immersion bath in MC-LR (IMM), and incorporation of dried cyanobacterial cells in fish diet. Fish were divided (20 individuals/aquarium). Each exposure treatment has two replicates (one exposure and the other is control [CTR]).

\section{Experiment I (IPM)}

Fish were intraperitoneally (IP) injected with $0.1 \mathrm{ml}$ of extracted MC-LR at a sublethal dose of $200 \mu \mathrm{g} / \mathrm{kg}[15,23,24]$, while the control group was IP injected with sterile $0.9 \%$ saline solution.

\section{Experiment II (IMM)}

Fish were immersed in the crude extract from $M$. aeruginosa containing MC-LR equivalent $500 \mu \mathrm{g} / \mathrm{L}$, while the control group was left in the aquarium water without MC-LR toxins [21].

\section{Experiment III (feeding toxic cyanobacterial cells in pelleted diets $[\mathrm{FC}]$ )}

Lyophilized cyanobacterial cells (containing $3500 \mu \mathrm{g} / \mathrm{g}$ MC-LR) were incorporated in fish diets, whereas the toxic algae were manually crushed in a mortar followed by sonication. Fish were fed with a dose rate of $60 \mu \mathrm{g} \mathrm{MC-LR/fish/day,} \mathrm{for} 21$ days [18].

\section{Clinical examination and sampling of the exposed fish}

During the three experiments, fish were observed for any clinical signs and behavioral abnormalities. After the end of $3^{\text {rd }}$ week of exposure, fish were sacrificed for a demonstration of any postmortem (PM) lesions.

After the exposure period, fish were sacrificed and sampled for histopathological examination. In addition, serum and specimens from gills, liver, kidneys, and muscular tissues were collected from different groups for the determination of LPO, liver function enzymes, and oxidative stress biomarkers.

\section{Kits for biochemical analysis}

Kits for liver function tests (alanine aminotransferase $[\mathrm{ALT}]$ and aspartate aminotransferase $[\mathrm{AST}]$ ), kits for lipid peroxide (malondialdehyde [MDA]), and for oxidative stress biomarkers are glutathione peroxidase (GPx), reduced glutathione, and catalase (CAT) were purchased from Biodiagnostic and Biotechnology Co., Egypt.

\section{Bleeding and serum collection}

Blood samples were collected weekly for 3 successive weeks from the caudal blood vessels. Fish body surface was wiped and dried out. Samples ( $3 \mathrm{ml} / \mathrm{fish}$ ) were assembled, relocated into Eppendorf tubes for serum collection [25], whereas serum detached by centrifugation at $2000 \mathrm{rpm}$ for $10 \mathrm{~min}$ and then stored at $-20^{\circ} \mathrm{C}$ till being used [26] for spectrophotometric measuring of enzymes of liver functions as AST and ALT (Lab. American Inc., USA).

\section{LPO and oxidative stress biomarkers}

Preparation of post-mitochondrial supernatant (PMS)

At the end of the experiments, the fish were sacrificed, and the liver, kidney, and gills were removed, 
weighed, rinsed with ice-cold physiological saline $(0.9 \% \mathrm{NaCl})$, (the gill filaments were trimmed from the gill arches, and the arches were discarded). The tissues were homogenized in chilled Tris buffer $(100 \mathrm{mM}, \mathrm{pH} 7.8 ; 1: 10 \mathrm{w} / \mathrm{v})$ using tissue homogenizer. The homogenates were centrifuged at $1000 \mathrm{~g}$ for $30 \mathrm{~min}$ at $4^{\circ} \mathrm{C}$ to obtain the PMS for various biochemical analyses.

\section{$L P O$}

It was determined by assessing the MDA concentration (the index of LPO) using the thiobarbituric acid (TBA) color reaction [27], this mixture was then heated at a temperature of $95^{\circ} \mathrm{C}$ for $30 \mathrm{~min}$ to form a TBA-reactive product. The absorbance of the resultant pink product was considered at $532 \mathrm{~nm}$. The values were determined as nmol MDA/mg protein.

\section{Antioxidant enzymes}

CAT enzyme activity

The CAT enzyme was assayed [28]. It reacts with a known quantity of $\mathrm{H}_{2} \mathrm{O}_{2}$, and the reaction is stopped after $1 \mathrm{~min}$ with a CAT inhibitor. In the presence of peroxidase, the remaining $\mathrm{H}_{2} \mathrm{O}_{2}$ reacts with 3,5-dichloro-2-hydroxybenzenesulfonic acid and 4-aminophenazone to form a chromophore, with a color intensity inversely proportional to the amount of CAT in the sample. The absorbance was measured spectrophotometrically at $510 \mathrm{~nm}$. Results are expressed in terms of $\mathrm{nmol}_{2} \mathrm{O}_{2}$ consumed $/ \mathrm{min} / \mathrm{mg}$ protein.

\section{GPx and glutathione reductase (GR) activities}

The GPx activity was measured spectrophotometrically and expressed as unit per milligram of protein (U/mg prot). One unit of GPx represents $1 \mu \mathrm{mol}$ oxidized nicotinamide adenine dinucleotide phosphate (NADPH)/min [29].

GPx activity was assayed by following the rate of NADPH oxidation at $340 \mathrm{~nm}$ by the coupled reaction with GR. The specific activity was determined using the extinction coefficient of $6.22 \mathrm{mM}^{-1} \mathrm{~cm}^{-1}$ [30].

GR activity was determined spectrophotometrically by measuring NADPH oxidation at $340 \mathrm{~nm}$ [31].

\section{Histopathological studies}

Tissue samples (livers, gills, and musculature) were collected from fish of the experimental and control groups after the end of the exposure period (3 weeks) and then were rapidly fixed inadequate amount $10 \%$ neutral buffered formalin for several hours, dehydrated, paraffin-embedded, and archived. Paraffin blocks were prepared, and sections of 3-5 mm were mounted and stained with hematoxylin and eosin stains [32].

\section{Statistical analysis}

Results are presented as the mean \pm standard error. The differences between the data of biochemical analysis from the different exposure experiments for 3 weeks were statistically analyzed using a t-test,
Duncan-test after ANOVA and simple correlation [33] to examine the significant effect of different concentrations and route dependent of cyanobacterial cells containing MC-LR on the studied parameters.

\section{Results}

\section{Mortality, clinical signs, and PM lesions}

No fish died throughout the whole exposure period in the three experiments. The exposed fish have been behaved like the control one, except in some fish, whereas there were obvious changes in swimming, lethargy, accumulation to one side of the aquaria, and rest on the aquaria floor. Moreover, there were some external alterations observed in some fish as detached scales, slight ascites, slight exophthalmia, opaqueness, and pale skin coloration. Some fish showing erythematic or hemorrhagic patches around the mouth, operculum and pectoral fins, and skin ulcers penetrate to the underlying musculature.

Gross pathological changes observed were severely congested gills, swollen congested liver with hemorrhagic patches in tips, with the congested engorged gall bladder.

\section{Histopathological findings}

The histopathological lesions of the exposed Nile tilapia (Figures-1-3) were, interestingly, varied by the dosage and route of administration.

\section{Effect of cyanobacteria cells on liver functions enzymes}

Results in Tables- 1 and 2 cleared that there is a significant difference $(\mathrm{p}<0.05)$ of the serum AST and serum ALT levels of $O$. niloticus regarding the exposure routes among the 3 weeks of exposure, whereas

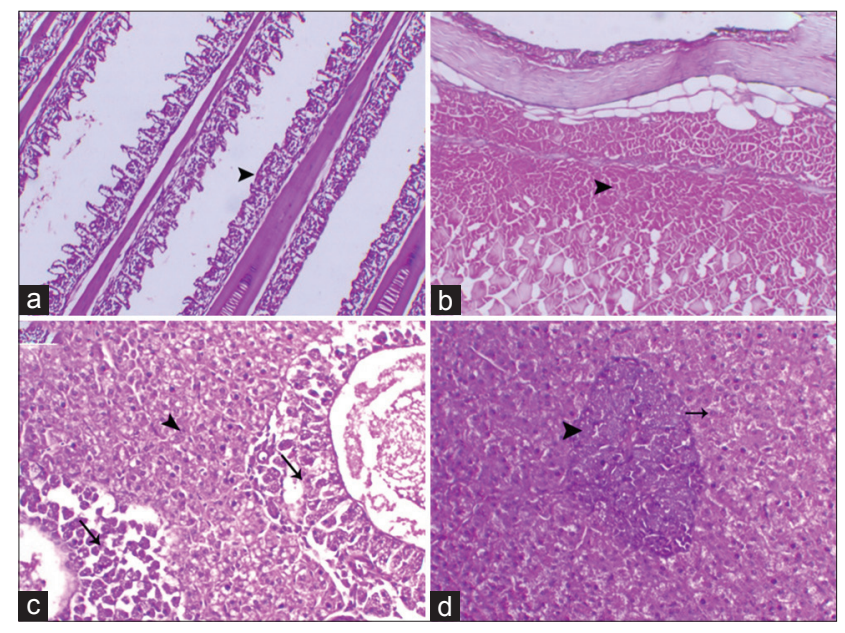

Figure-1: Photomicrographs of Group III (feeding cyanobacterial cells in the diet of Nile tilapia) showed marked adhesion of the secondary gill lamellae (arrowhead) with severe leukocytic infiltration (a), the subcutaneous layer with marked fragmentation of the underneath muscle fibers (arrowhead) with depletion of the goblet cells (b), and marked vacuolation and necrosis of the pancreatic portion (arrow), and the most of the hepatocytes were with vesicular nucleus with certain vacuolation mostly around the pancreatic portion (arrowhead) (c), with proliferated both pancreatic and hepatic cells (arrowhead and arrow, respectively) (d) (H and E stain, 200x). 
their levels were elevated in all exposed groups than that observed in control (CTR) group. In addition,

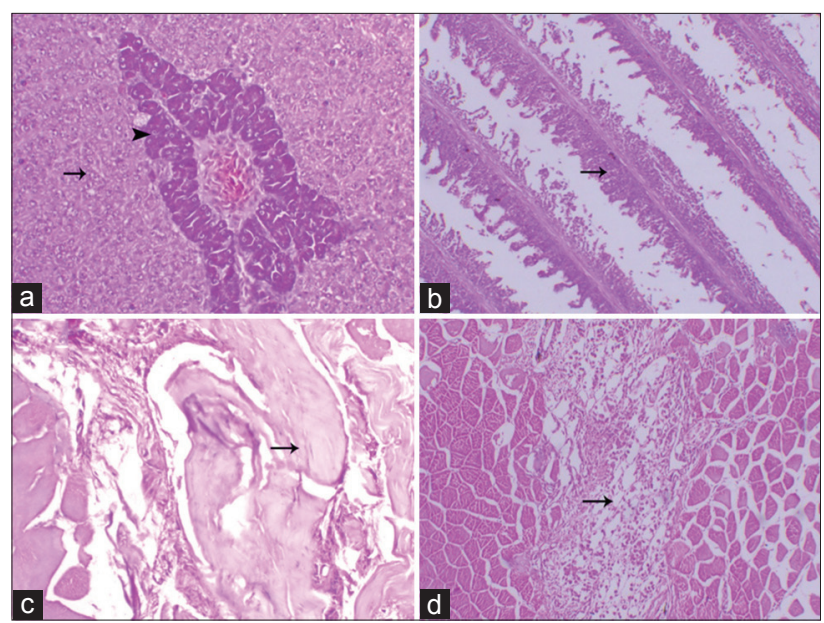

Figure-2: Photomicrographs of Group I (intraperitoneal injection of microcystin [MC-LR]) showed marked hyperplasia of pancreatic and hepatic cells (arrowhead and arrow, respectively) (a), adhesion of the gill lamellae (arrow) (b), and the subcutaneous layer of fish injected with MC at dose $500 \mu \mathrm{g} / \mathrm{kg}$ showing marked fragmentation of the muscle fiber(arrowhead), and hyalinization (arrow) (c), with showing focal large necrotic area within the muscle associated with marked leukocytic infiltration (arrow) (d), ( $H$ and $E$ stain, 200x).

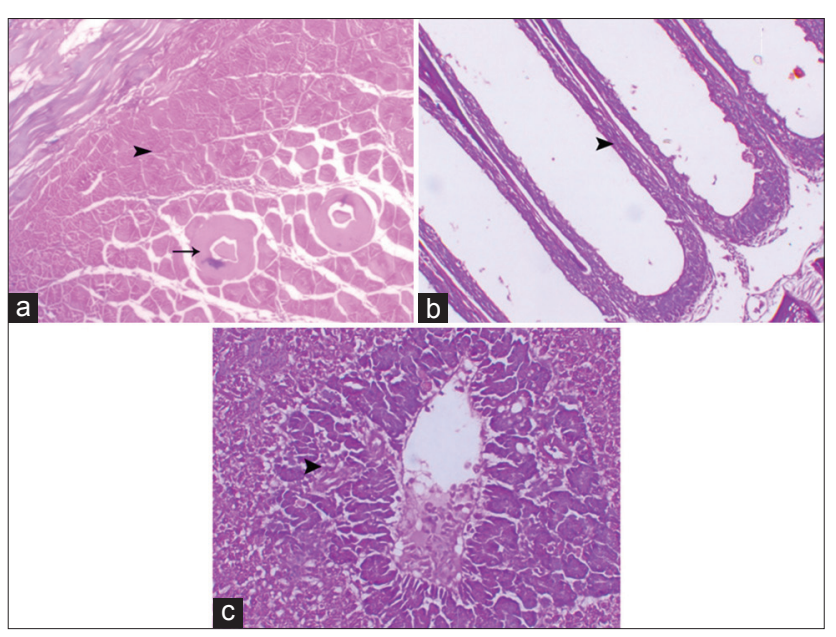

Figure-3: Photomicrographs of Group II (Nile tilapia fish treated with microcystin [MC-LR]) (immersion group) showed the subcutaneous layer of showing massive necrosis of subcutaneous muscle (arrow), marked fragmentation and vacuolation of the muscle fibers and interstitial edema (a), the gills showed complete adhesion of the secondary lamellae (arrowhead) (b), and hepatic degeneration (arrowhead) (c), (H and E stain, 200x). their levels were elevated steadily from the 1 st week to the $3^{\text {rd }}$ week of the experiment.

\section{Effect of cyanobacterial cells containing MC-LR on} LPO and antioxidant enzymes

Results investigated that there is a significant difference $(p<0.05)$ of the MDA levels (Table-3), and the activities of GR (Table-4), Gpx (Table-5), and CAT enzyme (Table-6), in the serum, kidney, and muscular tissue of the exposed fish regarding the exposure routes among the 3 weeks of exposure, whereas their levels elevated in all exposed groups than that observed in control (CTR) group. Furthermore, it was found that their levels in the serum, liver, and kidney samples were higher than that of gills and musculature. In addition, they were elevated steadily from the $1^{\text {st }}$ week to the $3^{\text {rd }}$ week of the experiment.

The activity of these biomarkers was significantly induced after 14 days of exposure in the liver, kidney, and serum $(\mathrm{p}<0.05)$ in exposed fish in IPM and FC groups and showed no significant changes in gills and musculature. The induction was evident mostly in the liver (which was the most affected organ).

\section{Discussion}

Among the toxic algal blooms, cyanotoxins are of environmental and associated with health problems of the exposed fish [6], which occurs, in Egypt, annually during the warm period of the year [34].

This study was particularly focused on the hazardous impacts of the cyanobacterial algae, $M$. aeruginosa containing MC-LR not only on the clinicopathological changes of exposed fish but also to serum biochemical parameters of Nile tilapia, exposed through three different exposure methods for 3-week period.

Several reviews studied their effects on tissues of fish species using the single route of exposure, herein, the study focused principally on exposing the fish to three methods (oral, immersion, and injection routes), to study all ways, by which the toxins may gain access to fish. The toxicological effects of MCs have been demonstrated in fish, when they were exposed by oral route [18,35], by immersion [36], or IP injected [15,37].

The clinical examination during fish exposure revealed no mortalities were recorded in any of the

Table-1: Effects of cyanobacterial cells and MC-LR on serum AST (IU/L) of O. niloticus by different exposure routes.

\begin{tabular}{lcccc}
\hline Exposure period & \multicolumn{3}{c}{ Mean \pm SE } \\
\cline { 2 - 5 } & CTR & IPM & IMM & FC \\
\hline $1^{\text {st }}$ week & $37.87 \pm 0.90^{\mathrm{A}}$ & $53.65 \pm 1.22^{\mathrm{C}}$ & $45.78 \pm 0.65^{\mathrm{C}}$ & $41.90 \pm 0.89^{\mathrm{C}}$ \\
$2^{\text {nd }}$ week & $36.41 \pm 0.68^{\mathrm{B}}$ & $60.87 \pm 1.23^{\mathrm{B}}$ & $50.84 \pm 0.73^{\mathrm{B}}$ & $42.26 \pm 0.37^{\mathrm{B}}$ \\
$3^{\text {rd }}$ week & $36.15 \pm 0.29^{\mathrm{C}}$ & $63.37 \pm 1.53^{\mathrm{A}}$ & $54.80 \pm 0.93^{\mathrm{A}}$ & $43.35 \pm 0.84^{\mathrm{A}}$ \\
\hline
\end{tabular}

Means within the same column of different letters are significantly different at $\mathrm{p}<0.05$. $O$. niloticus=Oreochromis niloticus, IPM=Intraperitoneal injection of MC-LR, IMM=Immersion bath in MC-LR, FC=Feeding toxic cyanobacterial cells in pelleted diets, $\mathrm{SE}=$ Standard error, $\mathrm{MC}=$ Microcystins, $\mathrm{AST}=$ Aspartate aminotransferase 
Available at www.veterinaryworld.org/Vol.10/August-2017/21.pdf

Table-2: Effects of cyanobacterial cells and MC-LR on serum ALT (IU/L) of $O$. niloticus by different exposure routes.

\begin{tabular}{lcccc}
\hline Exposure period & \multicolumn{3}{c}{ Mean \pm SE } \\
\cline { 2 - 5 } & CTR & IPM & IMM & FM \\
\hline $1^{\text {st }}$ week & $40.42 \pm 0.47^{\mathrm{C}}$ & $53.79 \pm 1.03^{\mathrm{D}}$ & $49.63 \pm 0.28^{\mathrm{C}}$ & $46.08 \pm 0.49^{\mathrm{B}}$ \\
$2^{\text {nd }}$ week & $43.03 \pm 0.61^{\mathrm{B}}$ & $62.65 \pm 0.26^{\mathrm{B}}$ & $54.63 \pm 0.54^{\mathrm{B}}$ & $46.13 \pm 0.31^{\mathrm{B}}$ \\
$3^{\text {rd }}$ week & $45.52 \pm 0.64^{\mathrm{A}}$ & $65.41 \pm 0.28^{\mathrm{A}}$ & $57.23 \pm 0.74^{\mathrm{A}}$ & $47.34 \pm 0.08^{\mathrm{A}}$ \\
\hline
\end{tabular}

Means within the same column of different letters are significantly different at $p<0.05$. $O$. niloticus=Oreochromis niloticus, IPM=Intraperitoneal injection of MC-LR, IMM=Immersion bath in MC-LR, FC=Feeding toxic cyanobacterial cells in pelleted diets, $\mathrm{SE}=$ Standard error, $\mathrm{MC}=$ Microcystins, $\mathrm{ALT}=$ Alanine aminotransferase

Table-3: Effects of cyanobacterial cells containing MC-LR on the MDA levels (nmol [ $\mu M$ MDA/mg protein]/g wet tissue) in the serum, gills, liver, kidney, and muscular tissue of $O$. niloticus by different exposure routes.

\begin{tabular}{llcccc}
\hline Exposure period & Sample & \multicolumn{3}{c}{ Mean \pm SE } \\
\cline { 3 - 6 } & & CTR & IPM & IMM & FC \\
\hline $1^{\text {st }}$ week & Serum & $26.78 \pm 0.63^{\mathrm{A}}$ & $30.27 \pm 0.57^{\mathrm{A}}$ & $28.70 \pm 0.34^{\mathrm{A}}$ & $32.79 \pm 0.45^{\mathrm{B}}$ \\
& Gills & $8.93 \pm 0.31^{\mathrm{C}}$ & $16.29 \pm 0.63^{\mathrm{C}}$ & $10.43 \pm 0.12^{\mathrm{D}}$ & $8.66 \pm 0.27^{\mathrm{D}}$ \\
& Liver & $11.57 \pm 0.26^{\mathrm{C}}$ & $30.47 \pm 0.15^{\mathrm{A}}$ & $26.00 \pm 0.42^{\mathrm{A}}$ & $28.40 \pm 0.60^{\mathrm{A}}$ \\
& Kidney & $18.42 \pm 0.63^{\mathrm{B}}$ & $21.09 \pm 0.27^{\mathrm{B}}$ & $19.32 \pm 0.37^{\mathrm{C}}$ & $17.45 \pm 0.42^{\mathrm{C}}$ \\
& Musculature & $27.53 \pm 0.52^{\mathrm{A}}$ & $11.53 \pm 0.32^{\mathrm{D}}$ & $13.61 \pm 0.32^{\mathrm{D}}$ & $9.60 \pm 0.26^{\mathrm{D}}$ \\
$2^{\text {nd }}$ week & Serum & $25.60 \pm 0.27^{\mathrm{A}}$ & $33.01 \pm 0.34^{\mathrm{A}}$ & $29.86 \pm 0.27^{\mathrm{A}}$ & $22.07 \pm 0.38^{\mathrm{B}}$ \\
& Gills & $9.40 \pm 0.07^{\mathrm{C}}$ & $14.19 \pm 0.34^{\mathrm{C}}$ & $11.15 \pm 0.14^{\mathrm{D}}$ & $8.53 \pm 0.22^{\mathrm{D}}$ \\
& Liver & $26.62 \pm 0.41^{\mathrm{A}}$ & $32.79 \pm 0.65^{\mathrm{A}}$ & $23.84 \pm 0.34^{\mathrm{B}}$ & $29.92 \pm 0.31^{\mathrm{A}}$ \\
& Kidney & $17.50 \pm 0.38^{\mathrm{B}}$ & $23.76 \pm 0.28^{\mathrm{B}}$ & $21.09 \pm 0.27^{\mathrm{B}}$ & $16.76 \pm 0.23^{\mathrm{C}}$ \\
& Musculature & $10.47 \pm 0.10^{\mathrm{C}}$ & $23.87 \pm 0.89^{\mathrm{B}}$ & $15.93 \pm 0.39^{\mathrm{D}}$ & $8.77 \pm 0.10^{\mathrm{D}}$ \\
$3^{\text {rd }}$ week & Serum & $25.40 \pm 0.45^{\mathrm{A}}$ & $35.21 \pm 0.54^{\mathrm{A}}$ & $29.86 \pm 0.27^{\mathrm{A}}$ & $34.00 \pm 0.13^{\mathrm{B}}$ \\
& Gills & $8.84 \pm 0.14^{\mathrm{C}}$ & $18.19 \pm 0.24^{\mathrm{C}}$ & $11.15 \pm 0.14^{\mathrm{D}}$ & $8.91 \pm 0.19^{\mathrm{D}}$ \\
& Liver & $26.09 \pm 0.42^{\mathrm{A}}$ & $36.79 \pm 0.85^{\mathrm{A}}$ & $23.84 \pm 0.34^{\mathrm{B}}$ & $30.13 \pm 0.18^{\mathrm{B}}$ \\
& Kidney & $16.93 \pm 0.49^{\mathrm{B}}$ & $28.76 \pm 0.18^{\mathrm{B}}$ & $21.09 \pm 0.27^{\mathrm{B}}$ & $18.07 \pm 0.16^{\mathrm{C}}$ \\
& Musculature & $10.68 \pm 0.28^{\mathrm{C}}$ & $20.17 \pm 0.80^{\mathrm{B}}$ & $15.93 \pm 0.39^{\mathrm{D}}$ & $9.58 \pm 0.18^{\mathrm{D}}$ \\
\hline
\end{tabular}

Means within the same column of different letters are significantly different at $p<0.05$. $O$. niloticus=Oreochromis niloticus, IPM=Intraperitoneal injection of MC-LR, IMM=Immersion bath in MC-LR, FC=Feeding toxic cyanobacterial cells in pelleted diets, $\mathrm{SE}=$ Standard error, $\mathrm{MC}=$ Microcystins, $\mathrm{MDA}=$ Malondialdehyde

Table-4: Effects of cyanobacterial cells containing MC-LR on GR level ( $\mathrm{nmol} / \mathrm{g}$ wet tissue) in the serum, gills, liver, kidney, and muscular tissue of $O$. niloticus by different exposure routes.

\begin{tabular}{llccrr}
\hline Exposure period & Sample & \multicolumn{3}{c}{ Mean \pm SE } \\
\cline { 3 - 6 } & & CTR & IPM & IMM & FC \\
\hline $1^{\text {st }}$ week & Serum & $6.44 \pm 0.11^{\mathrm{B}}$ & $5.79 \pm 0.08^{\mathrm{B}}$ & $5.73 \pm 0.06^{\mathrm{B}}$ & $5.43 \pm 0.12^{\mathrm{D}}$ \\
& Gills & $2.50 \pm 0.09^{\mathrm{E}}$ & $2.76 \pm 0.07^{\mathrm{E}}$ & $4.31 \pm 0.12^{\mathrm{C}}$ & $4.59 \pm 0.15^{\mathrm{E}}$ \\
& Liver & $8.35 \pm 0.11^{\mathrm{A}}$ & $7.31 \pm 0.04^{\mathrm{A}}$ & $7.40 \pm 0.05^{\mathrm{A}}$ & $8.48 \pm 0.17^{\mathrm{A}}$ \\
& Kidney & $5.32 \pm 0.11^{\mathrm{C}}$ & $5.63 \pm 0.06^{\mathrm{B}}$ & $5.89 \pm 0.06^{\mathrm{B}}$ & $6.55 \pm 0.09^{\mathrm{C}}$ \\
& Musculature & $4.53 \pm 0.23^{\mathrm{D}}$ & $4.12 \pm 0.13^{\mathrm{C}}$ & $2.83 \pm 0.06^{\mathrm{E}}$ & $2.59 \pm 0.08^{\mathrm{G}}$ \\
$2^{\text {nd }}$ week & Serum & $6.50 \pm 0.11^{\mathrm{B}}$ & $5.52 \pm 0.09^{\mathrm{B}}$ & $5.59 \pm 0.10^{\mathrm{B}}$ & $6.66 \pm 0.06^{\mathrm{C}}$ \\
& Gills & $4.46 \pm 0.18^{\mathrm{D}}$ & $3.84 \pm 0.07^{\mathrm{D}}$ & $3.92 \pm 0.08^{\mathrm{D}}$ & $4.73 \pm 0.24^{\mathrm{E}}$ \\
& Liver & $8.59 \pm 0.17^{\mathrm{A}}$ & $7.13 \pm 0.05^{\mathrm{A}}$ & $7.29 \pm 0.06^{\mathrm{A}}$ & $8.93 \pm 0.18^{\mathrm{A}}$ \\
& Kidney & $5.44 \pm 0.09^{\mathrm{C}}$ & $5.50 \pm 0.09^{\mathrm{B}}$ & $5.58 \pm 0.08^{\mathrm{B}}$ & $5.64 \pm 0.06^{\mathrm{D}}$ \\
$3^{\text {rd }}$ week & Musculature & $2.46 \pm 0.07^{\mathrm{E}}$ & $2.70 \pm 0.06^{\mathrm{E}}$ & $2.80 \pm 0.08^{\mathrm{E}}$ & $2.86 \pm 0.07^{\mathrm{G}}$ \\
& Serum & $6.60 \pm 0.11^{\mathrm{BC}}$ & $6.81 \pm 0.18^{\mathrm{B}}$ & $6.90 \pm 0.41^{\mathrm{B}}$ & $7.40 \pm 0.31^{\mathrm{B}}$ \\
& Gills & $4.55 \pm 0.10^{\mathrm{D}}$ & $4.75 \pm 0.30^{\mathrm{D}}$ & $5.05 \pm 0.20^{\mathrm{D}}$ & $5.65 \pm 0.15^{\mathrm{D}}$ \\
& Liver & $8.35 \pm 0.06^{\mathrm{A}}$ & $8.40 \pm 0.16^{\mathrm{A}}$ & $8.67 \pm 0.21^{\mathrm{A}}$ & $8.81 \pm 0.31^{\mathrm{A}}$ \\
& Kidney & $5.41 \pm 0.06^{\mathrm{C}}$ & $5.71 \pm 0.26^{\mathrm{C}}$ & $5.80 \pm 0.09^{\mathrm{C}}$ & $6.01 \pm 0.08^{\mathrm{C}}$ \\
& Musculature & $2.62 \pm 0.10^{\mathrm{E}}$ & $2.82 \pm 0.15^{\mathrm{E}}$ & $3.62 \pm 0.14^{\mathrm{E}}$ & $2.92 \pm 0.20^{\mathrm{E}}$ \\
\hline
\end{tabular}

Means within the same column of different letters are significantly different at $p<0.05$. $O$. niloticus=Oreochromis niloticus, IPM=Intraperitoneal injection of MC-LR, IMM=Immersion bath in MC-LR, FC=Feeding toxic cyanobacterial cells in pelleted diets, $\mathrm{SE}=$ Standard error, $\mathrm{MC}=$ Microcystins, $\mathrm{GR}=$ Glutathione reductase

three exposed groups and the control ones, although obvious behavioral, clinical, and PM changes were recorded and were directly in relation to the concentration and duration of the exposure to the cyanobacteria containing MC-LR [17,23].

The PM lesions noticed on examination of the internal organs including severely congested gills, swollen congested liver with hemorrhagic patches in tips, with congested engorged gall bladder of the exposed fish were like that observed in the toxicity of MCs in C. carpio L. [38], Oncorhynchus mykiss [39], and tilapias [37].

The toxicological impacts of MCs were clearly observed in various tissues of the exposed fish 
Table-5: Effects of cyanobacterial cells containing MC-LR on GPx activities (U/g tissue) in the serum, gills, liver, kidney, and muscular tissue of $O$. niloticus by different exposure routes.

\begin{tabular}{llcccc}
\hline Exposure period & Sample & \multicolumn{3}{c}{ Mean \pm SE } \\
\cline { 3 - 6 } & & CTR & IPM & IMM & FC \\
\hline $1^{\text {st }}$ Week & Serum & $15.66 \pm 0.26^{\mathrm{D}}$ & $13.93 \pm 0.34^{\mathrm{D}}$ & $15.16 \pm 0.20^{\mathrm{C}}$ & $16.29 \pm 0.33^{\mathrm{D}}$ \\
& Gills & $17.76 \pm 0.23^{\mathrm{C}}$ & $15.99 \pm 0.38^{\mathrm{D}}$ & $17.10 \pm 0.48^{\mathrm{C}}$ & $16.85 \pm 0.47^{\mathrm{D}}$ \\
& Liver & $28.62 \pm 0.54^{\mathrm{A}}$ & $26.36 \pm 0.68^{\mathrm{A}}$ & $28.00 \pm 0.42^{\mathrm{A}}$ & $33.25 \pm 0.98^{\mathrm{A}}$ \\
& Kidney & $23.70 \pm 0.67^{\mathrm{B}}$ & $20.68 \pm 0.32^{\mathrm{C}}$ & $22.40 \pm 0.14^{\mathrm{B}}$ & $25.81 \pm 0.36^{\mathrm{B}}$ \\
& Musculature & $15.70 \pm 0.62^{\mathrm{D}}$ & $14.06 \pm 0.75^{\mathrm{D}}$ & $15.00 \pm 0.68^{\mathrm{C}}$ & $17.14 \pm 0.17^{\mathrm{C}}$ \\
$2^{\text {nd }}$ Week & Serum & $24.19 \pm 0.34^{\mathrm{B}}$ & $16.83 \pm 0.36^{\mathrm{D}}$ & $20.73 \pm 0.62^{\mathrm{B}}$ & $29.62 \pm 0.71^{\mathrm{D}}$ \\
& Gills & $15.04 \pm 0.39^{\mathrm{D}}$ & $12.06 \pm 0.20^{\mathrm{E}}$ & $13.94 \pm 0.13^{\mathrm{D}}$ & $19.30 \pm 0.18^{\mathrm{G}}$ \\
& Liver & $28.37 \pm 0.52^{\mathrm{A}}$ & $22.59 \pm 0.75^{\mathrm{B}}$ & $26.30 \pm 0.26^{\mathrm{A}}$ & $39.47 \pm 0.44^{\mathrm{B}}$ \\
& Kidney & $18.18 \pm 0.33^{\mathrm{C}}$ & $13.86 \pm 0.27^{\mathrm{D}}$ & $15.03 \pm 0.15^{\mathrm{C}}$ & $20.22 \pm 0.29^{\mathrm{F}}$ \\
& Musculature & $15.68 \pm 0.90^{\mathrm{D}}$ & $12.81 \pm 0.20^{\mathrm{E}}$ & $13.99 \pm 0.70^{\mathrm{D}}$ & $19.43 \pm 0.39^{\mathrm{G}}$ \\
& Serum & $23.78 \pm 0.43^{\mathrm{B}}$ & $30.21 \pm 0.24^{\mathrm{C}}$ & $27.71 \pm 0.14^{\mathrm{B}}$ & $33.20 \pm 0.64^{\mathrm{C}}$ \\
& Gills Week & $15.41 \pm 0.50^{\mathrm{D}}$ & $20.19 \pm 0.82^{\mathrm{F}}$ & $19.12 \pm 0.62^{\mathrm{C}}$ & $21.39 \pm 0.42^{\mathrm{F}}$ \\
& Liver & $28.51 \pm 0.50^{\mathrm{A}}$ & $46.27 \pm 1.13^{\mathrm{A}}$ & $40.17 \pm 0.23^{\mathrm{A}}$ & $48.57 \pm 1.53^{\mathrm{A}}$ \\
& Kidney & $17.26 \pm 0.54^{\mathrm{C}}$ & $22.05 \pm 0.29^{\mathrm{E}}$ & $17.15 \pm 0.29^{\mathrm{D}}$ & $25.00 \pm 0.89^{\mathrm{E}}$ \\
& Musculature & $15.51 \pm 0.47^{\mathrm{D}}$ & $20.24 \pm 0.50^{\mathrm{E}}$ & $18.24 \pm 0.40^{\mathrm{D}}$ & $24.14 \pm 0.40^{\mathrm{E}}$ \\
\hline
\end{tabular}

Means within the same column of different letters are significantly different at $p<0.05$. GPx=Glutathione peroxidase, $O$. niloticus=Oreochromis niloticus, IPM=Intraperitoneal injection of MC-LR, IMM=Immersion bath in MC-LR, FC=Feeding toxic cyanobacterial cells in pelleted diets, $\mathrm{SE}=$ Standard error, $\mathrm{MC}=$ Microcystins

Table-6: Effects of cyanobacterial cells containing MC-LR on CAT activity ( $\mu \mathrm{mol} \mathrm{O}^{2} / \mathrm{min} / \mathrm{mg}$ protein/g wet tissue) in the serum, gills, liver, kidney, and muscular tissue of $O$. niloticus by different exposure routes.

\begin{tabular}{llcccc}
\hline Exposure period & Sample & \multicolumn{3}{c}{ Mean \pm SE } \\
\cline { 3 - 6 } & & CTR & IPM & IMM & FC \\
\hline $1^{\text {st }}$ week & Serum & $20.06 \pm 0.24^{\mathrm{B}}$ & $19.06 \pm 0.33^{\mathrm{C}}$ & $19.31 \pm 0.28^{\mathrm{B}}$ & $22.88 \pm 0.40^{\mathrm{F}}$ \\
& Gills & $8.29 \pm 0.24^{\mathrm{C}}$ & $8.12 \pm 0.50^{\mathrm{D}}$ & $8.37 \pm 0.17^{\mathrm{C}}$ & $8.78 \pm 0.17^{\mathrm{I}}$ \\
& Liver & $38.89 \pm 0.67^{\mathrm{A}}$ & $37.28 \pm 0.39^{\mathrm{A}}$ & $38.07 \pm 0.23^{\mathrm{A}}$ & $44.71 \pm 0.62^{\mathrm{B}}$ \\
& Kidney & $20.09 \pm 0.27^{\mathrm{B}}$ & $18.63 \pm 0.33^{\mathrm{C}}$ & $18.99 \pm 0.21^{\mathrm{B}}$ & $21.33^{\mathrm{B}} \pm 0.59^{\mathrm{F}}$ \\
& Musculature & $2.67 \pm 0.08^{\mathrm{D}}$ & $2.26 \pm 0.05^{\mathrm{E}}$ & $2.48 \pm 0.10^{\mathrm{D}}$ & $2.86 \pm 0.05^{\mathrm{IJ}}$ \\
$2^{\text {nd }}$ week & Serum & $18.80 \pm 0.35^{\mathrm{B}}$ & $16.95 \pm 0.37^{\mathrm{C}}$ & $17.53 \pm 0.11^{\mathrm{B}}$ & $29.00 \pm 0.33^{\mathrm{D}}$ \\
& Gills & $7.76 \pm 0.27^{\mathrm{C}}$ & $7.53 \pm 0.17^{\mathrm{D}}$ & $7.99 \pm 0.08^{\mathrm{C}}$ & $11.29 \pm 0.26^{\mathrm{H}}$ \\
& Liver & $37.70 \pm 0.54^{\mathrm{A}}$ & $33.00 \pm 0.26^{\mathrm{B}}$ & $35.69 \pm 0.37^{\mathrm{A}}$ & $46.76 \pm 0.38^{\mathrm{B}}$ \\
& Kidney & $18.65 \pm 0.53^{\mathrm{B}}$ & $16.70 \pm 0.37^{\mathrm{C}}$ & $17.66 \pm 0.45^{\mathrm{B}}$ & $24.34 \pm 0.32^{\mathrm{E}}$ \\
& Musculature & $2.48 \pm 0.07^{\mathrm{D}}$ & $2.08 \pm 0.03^{\mathrm{E}}$ & $2.28 \pm 0.05^{\mathrm{D}}$ & $3.12 \pm 0.08^{\mathrm{II}}$ \\
$3^{\text {rd }}$ week & Serum & $18.84 \pm 0.76^{\mathrm{B}}$ & $32.37 \pm 0.17^{\mathrm{C}}$ & $23.67 \pm 0.27^{\mathrm{C}}$ & $33.77 \pm 0.07^{\mathrm{C}}$ \\
& Gills & $8.14 \pm 0.35^{\mathrm{C}}$ & $15.14 \pm 0.20^{\mathrm{E}}$ & $14.04 \pm 0.40^{\mathrm{E}}$ & $16.08 \pm 0.48^{\mathrm{E}}$ \\
& Liver & $37.91 \pm 0.53^{\mathrm{A}}$ & $47.23 \pm 0.28^{\mathrm{A}}$ & $45.33 \pm 0.28^{\mathrm{A}}$ & $49.93 \pm 0.26^{\mathrm{A}}$ \\
& Kidney & $18.09 \pm 0.71^{\mathrm{B}}$ & $28.30 \pm 0.39^{\mathrm{B}}$ & $22.58 \pm 0.17^{\mathrm{B}}$ & $29.50 \pm 0.37^{\mathrm{B}}$ \\
& Musculature & $12.49 \pm 0.15^{\mathrm{D}}$ & $25.39 \pm 0.40^{\mathrm{D}}$ & $21.72 \pm 0.13^{\mathrm{D}}$ & $24.37 \pm 0.20^{\mathrm{D}}$ \\
\hline
\end{tabular}

Means within the same column of different letters are significantly different at $p<0.05$. CAT=Catalase.

O. niloticus=Oreochromis niloticus, IPM=Intraperitoneal injection of MC-LR, IMM=Immersion bath in MC-LR, FC=Feeding toxic cyanobacterial cells in pelleted diets, $\mathrm{SE}=$ Standard error, $\mathrm{MC}=$ Microcystins

species; renal tissue (causing nephrotoxicity) of rainbow trout [39], as well as in the tilapia [40], in the branchial tissue of common carp [38], in the gastrointestinal tract of tilapia [40], in the heart of brown trout [41,42], and in the brain tissue [36].

In this study, regarding the histopathological findings of the exposed $O$. niloticus, moderate-to-severe histopathological changes were present in the livers, musculature, and gills of the exposed fish in the three experiments. Our findings were nearly in concordance to that of Fischer and Dietrich [14], Carbis et al. [43] in C. carpio, in O. mossambicus [15], and in $O$. niloticus [16].

The histopathological findings (for intraperitoneal injection, immersion, and oral route groups) of the exposed $O$. niloticus indicated that cyanobacteria produce potent toxins (Cyanotoxins, MCs) (which are mainly, hepatotoxins), which, not only be accumulated in the tissues of Nile tilapia [44], especially the liver [45] but also can change the architecture of the hepatocytes and impair their functions [46-48].

The histopathological findings of the liver of exposed fish showed vacuolization of hepatocytes [40,49], which may indicate an imbalance between the synthesis rate in the parenchymal cells and the release rate of these substances into the systemic circulation. Furthermore, necrotic hepatocytes found is evident previously described by Fischer and Dietrich [14], Mitsoura et al. [50] in C. carpio, which is caused by the hepatotoxic effects of MC-LR.

Our findings were mainly focused in the liver because the liver is the principle organ of detoxification of toxicants [51] and the accumulation of MCs in its tissue [52]. 
Regarding the effects on liver function enzymes, our finding showed significant elevation of serum ALT and serum AST enzymes with dose- and time-dependent manner. Our results were parallel to that of Rabergh et al. [38], Kopp and Heteša [53], who investigated their elevation in the serum of the $\mathrm{MC}$ intoxicated common carp after $2 \mathrm{~h}$ of intraperitoneal injection of toxin. In addition, our results were in concordance to that retrieved by Vajcova et al. [54], where their levels were similarly elevated in silver carp following intraperitoneal exposure to pure MC.

MC-LR-induced hepatotoxicity was noticed through the elevation of serum ALT and serum AST enzyme activities, which may be correlated to the increase in serum bile acid and the concentration of bilirubin $[41,43]$.

Concerning the results of oxidative stress biomarkers, our findings showed elevated MDA levels and the activities of GR, GPx, and CAT enzymes, in the serum, kidney, and liver of the exposed fish among the 3 weeks of exposure to the control group. Furthermore, in a time-dependent manner, their activities were significantly induced after 14 days of exposure in liver, kidney, and serum in fish in IP injected and oral route exposed groups.

LPO is principally important for aquatic biota because they normally contain large quantities of highly unsaturated fatty acids [55].

These results were not parallel to that of Cazenave et al. [36], who reviewed significant changes in GR and GPx enzyme activities in gills of Corydoras paleatus exposed to MC-RR by immersion. The difference in the results may be due to species differences, different exposure period, and due to exposure to the different type of MC (MC-RR).

Furthermore, our findings were in concordance to that of experimentally exposed Nile tilapia, whereas, these biomarkers were elevated when tilapia orally exposed to cyanobacterial cells for 2-3 weeks [18], and IP injected with an acute dose of pure MCs [37].

\section{Conclusion}

From our results, this study addresses the possible toxicological impacts of toxic $M$. aeruginosa containing MC-LR to Nile tilapia, and the results investigated that MC-LR is toxic to Nile tilapia in different routes of exposure as well as different doses.

\section{Authors' Contributions}

AMAK has carried out the research work and did data analysis. While HMRAL has designed, supervised the experiment, write and follow-up the manuscript. All authors read and approved the final manuscript.

\section{Acknowledgments}

The authors would like to thank Colleagues of Fish Diseases Group (Prof. Dr. Riad H. Khalil, Prof. Dr. Talaat T. Saad, and Dr. Mahmoud T. Amer),
Department of Poultry and Fish Diseases, Faculty of Veterinary Medicine, Alexandria University, for their support and collaboration in the realization of this study. We declare that this research had not received any specific fund.

\section{Competing Interests}

The authors declare that they have no competing interests.

\section{References}

1. GAFARD. (2013) General Authority for Fish Resources. Fish Production Statistics, 2012. Ministry of Agriculture, Cairo, Egypt.

2. El-Sayed, A.F.M. (2006) Tilapia Culture. CABI Publishing, CABI International, Willingford.

3. Oh, H.M., Lee, S.J., Jang, M.H. and Yoon, B.D. (2000) Microcystin production by Microcystis aeruginosa in a phosphorus-limited chemostat. Appl. Environ. Microbiol., 66: 176-179.

4. Carmichael, W.W., Azevedo, S.M., An, J.S., Molica, R.J., Jochimsen, E.M. and Lau, S. (2001) Human fatalities from Cyanobacteria: Chemical and biological evidence for cyanotoxins. Environ. Health Perspect., 109: 663-668.

5. Chen, T., Wang, Q., Cui, J., Yang, W., Shi, Q., Hua, Z., Ji, J. and Shen, P. (2005) Induction of apoptosis in mouse liver by microcystin-LR. Mol. Cell. Proteomics, 4: 958-974.

6. Chen, J., Xie, P., Li, L. and Xu, J. (2009a) First identification of the hepatotoxic microcystins in the serum of a chronically exposed human population together with indication of hepatocellular damage. Toxicol. Sci., 108: 81-89.

7. Trincheta, I., Djediatb, C., Huetc, H., Daoa, S.P. and Ederya, M. (2011) Pathological modifications following sub-chronic exposure of medaka fish (Oryzias latipes) to microcystin-LR. Reprod. Toxicol., 32(3): 329-340.

8. Chen, J., Zhang, D., Xie, P., Wang, Q. and Ma, Z. (2009b) Simultaneous determination of microcystin contaminations in various vertebrates (fish, turtle, duck and water bird) from a large eutrophic Chinese lake, Lake Taihu, with toxic Microcystis blooms. Sci. Total Environ., 407: 3317-3322.

9. Susana, R., Francisca, F., Youness, O. and Ángel, B. (2012) Assessment of microcystins in lake water and fish (Mugilidae, Liza sp.) in the largest Spanish coastal lake. Environ. Monit. Assess., 184: 939-949.

10. Schmidt, J.R., Shaskus, M., Estenik, J.F., Oesch, C., Khidekel, R. and Boyer, G.L. (2013) Variations in the microcystin content of different fish species collected from a eutrophic lake. Toxins, 5(5): 992-1009.

11. Paerl, H.W. and Paul, V.J. (2012) Climate change: Links to global expansion of harmful cyanobacteria. Water Res., 46(5): 1349-1363.

12. Zakaria, A.M., El-Sharouny, H.M. and Ali, W.S.M. (2006) Microcystin production in benthic mats of Cyanobacteria in the Nile River and irrigation canals, Egypt. Toxicon., 47: 584-590.

13. El-Sheekh, M.M., Khairy, H.M. and El-Shenody, R.A. (2010) Allelopathic effects of the cyanobacterium Microcystis aeruginosa Kutzing on the growth and photosynthetic pigments of some algal species. Allelo J., 26: 275-290.

14. Fischer, W.J. and Dietrich, D.R. (2000) Pathological and biochemical characterization of microcystin-induced hepatopancreas and kidney damage in carp (Cyprinus carpio). Toxicol. Appl. Pharmacol., 164: 73-81.

15. Kanchana, M.P., Srisudha, S. and Gunasekaran, P. (2012) Toxicological evaluation of Cyanobacterium anabeanopsis abijatae in tilapia (Oreochromis mossambicus). Int. J. Curr. Res., 4(5): 42-46.

16. Sanad, S.M., Al-Gamaal, M.A. and Hemmaid, D.K. (2015) Histopathological Changes in the Liver of the Nile 
Fish Oreochromis niloticus Fed on the Blue-Green Algae Microcystis aeruginosa Under Laboratory Conditions. International Conference on Biological, Civil and Environmental Engineering (BCEE-2015), Bali (Indonesia).

17. Pichardo, S., Jos, A., Zurita, J.L., Salguero, M., Camean, A.M. and Repetto, G. (2007) Acute and sub-acute toxic effects produced by microcystin-YR on the fish cell lines RTG-2 and PLHC-1. Toxicol. In Vitro, 21: 1460-1467.

18. Jos, A., Pichardo, S., Prieto, A.I., Repetto, G., Vázquez, C.M., Moreno, I. and Cameán, A.M. (2006) Toxic cyanobacterial cells containing microcystins induce oxidative stress in exposed tilapia fish (Oreochromis sp.) under laboratory conditions. Aquat Toxicol., 72: 261-271.

19. Prieto, A.I., Pichardo, S., Jos, A., Moreno, I. and Cameán, A.M. (2007) Time-dependent oxidative stress responses after acute exposure to toxic cyanobacterial cells containing microcystins in tilapia fish (Oreochromis niloticus) under laboratory conditions. Aquat Toxicol., 84: 337-345.

20. Al-Kahtani, M.A. and Fathi, A.A. (2008) Physiological studies on tilapia fish (Oreochromis niloticus) as influenced by the cyanobacterial toxins microcystins. J. Biol. Sci., 8(7): 1226-1230.

21. Wiegand, C., Pflugmacher, S., Oberemm, A., Meems, N., Beattie, K.A., Steinberg, C.E.W. and Codd, G.A. (1999) Uptake and effects of microcystin-LR on detoxication enzymes of early life stages of the zebra fish (Danio rerio). Environ. Toxicol., 14(1): 89-95.

22. Moreno, I.M., Maraver, J., Aguete, E.C., Leao, M., GagoMartínez, A. and Camean, A.M. (2004) Decomposition of microcystin-LR, microcystin-RR, and microcystin-YR in water samples submitted to in vitro dissolution tests. J. Agric. Food Chem., 52: 5933-5938.

23. Ibrahem, M.D., Khairy, H.M. and Ibrahim, M.A. (2012) Laboratory exposure of Oreochromis niloticus to crude microcystins (containing microcystin-LR) extracted from Egyptian locally isolated strain (Microcystis aeruginosa Kützing): Biological and biochemical studies. Fish Physiol. Biochem., 38: 899-908.

24. Gupta, U.S. and Guha, S. (2006) Microcystin toxicity in a freshwater fish, Heteropneustes fossilis (Bloch). Curr. Sci., 91(9): 1261-1270.

25. Pedroso, G.L., Hammes, T.O., Escobar, T.D., Fracasso, L.B., Forgiarini, L.F. and da Silveira, T.R. (2012) Blood collection for biochemical analysis in adult zebrafish. J. Vis. Exp., (63): e3865.

26. Zang, L., Shimada, Y., Nishimura, Y., Tanaka, T. and Nishimura, N. (2013) A novel, reliable method for repeated blood collection from aquarium fish. Zebrafish, 10(3): 425-432.

27. Abdel-Latif, H.M.R. and El-Euony, O.I. (2016) Effects of rotenone on liver functions, antioxidants and lipid peroxidation of Nile tilapia fingerlings. Alex. J. Vet. Sci., 51(1): 186-193.

28. Vasylkiva, O.Y., Kubraka, O.I., Storeyb, K.B. and Lushchaka, V.I. (2011) Catalase activity as a potential vital biomarker of fish intoxication by the herbicide aminotriazole. Pestic. Biochem. Physiol., 101(1): 1-5.

29. Branco, V., CanPERL, J., Lu, J., Holmgren, A. and Carvalho, C. (2012) Mercury and selenium interaction in vivo: Effects on thioredoxin reductase and glutathione peroxidase. Free Radic. Biol. Med., 52(4): 781-793.

30. Zhu, Y., Chen, Y., Liu, Y., Yang, H., Liang, G. and Tian, L. (2012) Effect of dietary selenium level on growth performance, body composition and hepatic glutathione peroxidase activities of largemouth bass Micropterus salmoide. Aquac. Res., 43(11): 1660-1668.

31. Srikanth, K., Pereira, E., Duarte, A.C. and Ahmad, I. (2013) Glutathione and its dependent enzymeshmad, I. (2013) (2013) composition and hepatic glutathiofish-a review. Environ. Sci. Pollut. Res., 20(4): 2133-2149.

32. Reddy, P.B. and Rawat, S.S. (2013) Assessment of aquatic pollution using histopathology in fish as a protocol. Int. Res. J. Environ. Sci., 2(8): 79-82.

33. SAS Statistical Analysis System. (1987) User's Guide Statistics. SAS Institute Cary, North Carolina.

34. Mohamed, Z.A., Carmichael, W.W. and Hussein, A.A. (2003) Estimation of microcystins in the freshwater fish Oreochromis niloticus in an Egyptian fish farm containing a Microcystis bloom. Environ. Toxicol., 18: 137-141.

35. Li, X., Xie, P. and Chen, J. (2005) In vivo studies on toxin accumulation in liver and ultrastructural changes of hepatocytes of the phytoplanktivorous Bighead carp I.P. Injected with extracted microcystins. Toxicon, 46: 533-545.

36. Cazenave, J., Bistoni, M.A., Pesce, S.F. and Wunderlin, D.A. (2006) Differential detoxification and antioxidant response in diverse organs of Corydoras paleatus experimentally exposed to microcystin-RR. Aquat. Toxicol., 76: 1-12.

37. Prieto, A.I., Jos, A., Pichardo, S., Moreno, I.M. and Camean, A.M. (2006) Differential oxidative stress responses to microcystins LR and RR in intraperitoneally exposed tilapia fish (Oreochromis sp.). Aquat. Toxicol., 77: 314-321.

38. Rabergh, C.M.I., Bylund, G. and Eriksson, J.E. (1991) Histopathological effects of microcystin-LR, a cyclic peptide toxin from the cyanobacterium (blue-green algae) Microcystis aeruginosa, on common carp (Cyprinus carpio L.). Aquat. Toxicol., 20: 131-146.

39. Kotak, B.G., Semalulu, S., Fritz, D.L., Prepas, E.E., Hrudey, S.E. and Coppock, R.W. (1996) Hepatic and renal pathology of intraperitoneally administered microcystin-LR in rainbow trout (Oncorhyncus mykiss). Toxicon, 34: $517-525$.

40. Molina, R., Moreno, I., Pichardo, S., Jos, A., Moyano, R. and Monterde, J.G. (2005) Acid and alkaline phosphatase activities and pathological changes induced in Tilapia fish (Oreochromis sp.) exposed subchronically to microcystins from toxic cyanobacterial blooms under laboratory conditions. Toxicon, 46: 725-735.

41. Best, J.H., Eddy, F.B. and Codd, G.A. (2001) Effects of purified microcystin-LR and cell extracts of Microcistis strains PCC 7813 and CYA 43 on cardiac function in brown trout (Salmo trutta) alevine. Fish Physiol. Biochem., 24: 171-178.

42. Liu, Y., Song, L., Li, X. and Liu, T. (2002) The toxic effects of microcystin-LR on embryo-larval and juvenile development of loach, Misguruns mizolepis Gunthe. Toxicon, 40: 395-399.

43. Carbis, C.R., Rawlin, G.T., Mitchell, G.F., Anderson, J.W. and McCauley, I. (1996) The histopathology of carp, Cyprinus carpio L., exposed to microcystins by gavage, immersion and intraperitoneal administration. J. Fish Dis., 19: 199-207.

44. Soares, R.M., Magalhaes, V.F. and Azevedo, S. (2004) Accumulation and depuration of microcystins (cyanobacteria hepatotoxins) in Tilapia rendalli (Cichlidae) under laboratory conditions. Aquat. Toxicol., 70: 1-10.

45. Zhao, M., Xie, S., Zhu, X., Yang, Y., Gan, N. and Song, L. (2006) Effect of dietary cyanobacteria on growth and accumulation of microcystins in Nile tilapia (Oreochromis niloticus). Aquaculture, 261: 960-966.

46. Amrani, A., Nasri, H., Azzouz, A., Kadi, Y. and Bouaïcha, N. (2014) Variation in cyanobacterial hepatotoxin (microcystin) content of water samples and two species of fishes collected from a shallow lake in Algeria. Arch. Environ. Contam. Toxicol., 66(3): 379-389.

47. Snyder, S., Goodwin, A. and Freeman, D. (2002) Evidence that channel catfish Ictalurus punctatus mortality is not linked to ingestion of the hepatoxin microcystin-LR. J. Fish Dis., 25: 275-278.

48. Li, X., Liu, Y., Song, L. and Liu, J. (2003) Responses of antioxidant systems in the hepatocytes of common carp (Cyprinus carpio L.) to the toxicity of microcystin-LR. Toxicon, 42: 85-89.

49. Atencio, L., Moreno, I., Jos, A., Pichardo, S., Moyano, R., 
Blanco, A. and Camean, A. (2008) Dose-dependent antioxidant responses and pathological changes in tenca (Tinca tinca) after acute oral exposure to Microcystis under laboratory conditions. Toxicon, 52: 1-12.

50. Mitsoura, A., Kagalou, I., Papaioannou, N., Berillis, P., Mente, E. and Papadimitriou, T. (2013) The presence of microcystins in fish Cyprinus carpio tissues: A histopathological study. Int. Aquat. Res., 5: 8.

51. Channa, A. and Mir, I.H. (2009) Distribution of neutral lipids in the intestinal tract and liver of Schizothorax curvifrons Heckel: A histochemical study. Indian J. Appl. Pure Biol., 24: 285-288.

52. Chen, J., Xie, P., Zhang, D., Ke, Z. and Yang, H. (2006) In situ studies on the bioaccumulation of microcystins in the phytoplanktivorous silver carp (Hypophthalmichthys molitrix) stocked in Lake Taihu with dense toxic Microcystis bloom. Aquaculture, 261: 1026-1038.

53. Kopp, R. and Heteša, J. (2000) Changes of haematological indices of juvenile carp (Cyprinus carpio L.) under the influence of natural populations of cyanobacterial water blooms. Acta. Vet. Brno., 69: 131-137.

54. Vajcova, V., Mavratil, S. and Palikova, M. (1998) The effect of intraperitoneally applied pure microcystin LR on haematological, biochemical and morphological indices of silver carp (Hypophthalmichthys molitrix Val.). Acta. Vet. Brno., 67: 281-287.

55. Huang, C.H., Chang, R.J., Huang, S.L. and Chen, W. (2003) Dietary vitamin E supplementation affects tissue lipid peroxidation of hybrid tilapia, Oreochromis niloticus $\times$ O. aureus. Comp. Biochem. Physiol. B, 134: 265-270.

$* * * * * * * *$ 